\title{
Annual checkup
}

7 his issue marks the first-year anniversary of Neurology ${ }^{\circledR}$ Clinical Practice. NCP provides high-quality peer-reviewed articles on the state of current practice

in topics of clinical interest and plays a unique role in educating neurologists and general health care practitioners by publishing concise updates on what's new in neurology. Our goal is to help practicing neurologists to best treat the 1 in 6 people worldwide who have a neurologic disorder.

NCP reaches nearly 20,000 individual subscribers (20\% international) and just over 3,250 institutions and consortia worldwide. There have been more than 7,500 iPad app downloads (53\% international) to date. At least one article per issue is freely accessible online to nonsubscribers along with all errata, editorials, and reader correspondence.

NCP has established some unique article types and will expand these as needed. Clinical and Ethical Challenges articles explore problems faced by the practicing neurologist caring for a complex patient or addressing a challenging clinical problem or ethical dilemma. Eye on Practice articles highlight issues related to office function, such as incorporation of electronic medical records, as well as discussions of health policy issues with special emphasis on changes in health care policy as they affect neurologists. Five New Things articles (the most downloaded article type to date) update health care practitioners on emerging issues in neurologic subspecialties within and outside of their areas of expertise. NCP features debate from leaders in the field of neurology in the Current Controversies series and welcomes feedback from readers in the correspondence section, The Nerve! Readers Speak.

This anniversary issue introduces 2 new recurring features. Statistics in Clinical Practice will help simplify commonly used statistical principles so that the clinical practitioner can more easily understand the statistical and biological importance of results described in research papers. Practice Across Borders will investigate how clinical practitioners in different parts of the world approach a patient with a particular neurologic presentation. With these articles, we seek to elucidate diagnostic and therapeutic differences around the world and why they exist, with an eye toward greater understanding of the challenges facing our US and international colleagues in clinical practice.

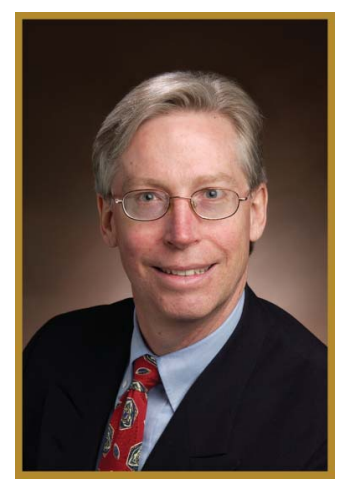


Heartfelt thanks to our contributors, peer reviewers, and readers for making the first year of Neurology: Clinical Practice a great success. As always, we invite you to consider authoring and submitting an article of relevance to the practicing clinical neurologist.
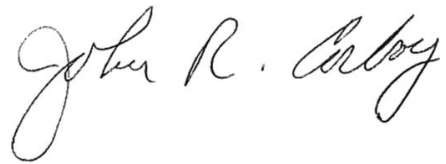

John R. Corboy, MD, FAAN

\section{Download Neurology ${ }^{\circledR}$ Clinical Practice for the} $\mathrm{iPad}^{\circledR}$

The same information so critical to your practice is now brought to you on the $\mathrm{iPad}^{\circledR}$. This dynamic app optimizes the best in digital technology to enhance the reading experience with article-sharing features, multimedia, links, and more.

\section{Enjoy the benefits:}

- Easy-to-read articles you can share via email and social media

- Adjustable text sizing with "pinch and zoom" technology

- Engaging multimedia videos, images, and data supplements

- Ability to store downloaded issues

- Convenient notification when a new issue is available 


\title{
Neurology ${ }^{\circ}$ Clinical Practice
}

\author{
Annual checkup \\ John R. Corboy \\ Neurol Clin Pract 2012;2;263-264 \\ DOI 10.1212/CPJ.0b013e318278f3a2
}

This information is current as of December 10, 2012

Updated Information \&

Services

Permissions \& Licensing

Reprints including high resolution figures, can be found at:

http://cp.neurology.org/content/2/4/263.full.html

Information about reproducing this article in parts (figures,tables) or in its entirety can be found online at:

http://cp.neurology.org/misc/about.xhtml\#permissions

Information about ordering reprints can be found online:

http://cp.neurology.org/misc/addir.xhtml\#reprintsus

Neurol Clin Pract is an official journal of the American Academy of Neurology. Published continuously since 2011, it is now a bimonthly with 6 issues per year. Copyright ( 2012 American Academy of Neurology. All rights reserved. Print ISSN: 2163-0402. Online ISSN: 2163-0933.

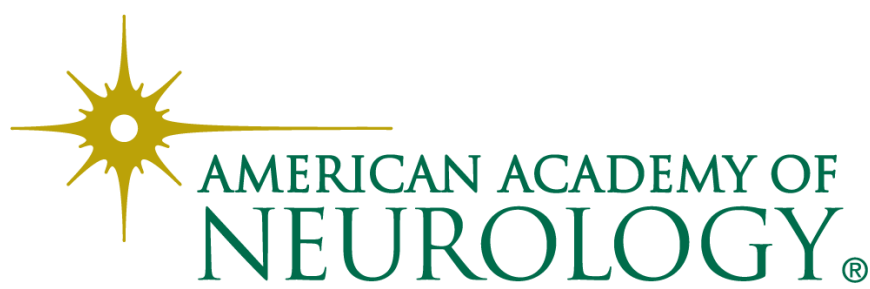

